\title{
The Influence of Destination Brands on the Satisfaction and Revisit Intention of Foreign Tourists at the Agro-tourism of Ceking Rice Field Terrace in Bali
}

\author{
I Putu Wahyu Wicaksana ${ }^{1}$, I G A Oka Suryawardani², Ratna Komala Dewi ${ }^{1}$ \\ ${ }^{1}$ Agribusiness Study Program, Faculty of Agriculture, Udayana University \\ ${ }^{2}$ Centre of Excellence in Tourism, Udayana University \\ Corresponding Author: wahyuwicaksanaa@gmail.com
}

\section{ARTICLE INFO}

Received

14 August 2020

Accepted

2 September 2020

Available online

30 September 2020

\begin{abstract}
Agrotourism attraction of Ceking Rice Field Terrace Village is a natural panorama of rice fields terrace has been recognized as heritage that should be preserved. The purpose of this study is to find out the influence of destination brands on the interest of foreign tourists in Ceking Rice Field Terrace Agrotourism and the obstacles faced in building destination brands in Ceking Rice Field Terrace tourist destinations. The independent variables of this research are part of the brand destination, namely brand awareness, brand image and brand association. The dependent variables are customer satisfaction and revisit intention. Research was design based on structural equation model. Data was analyzed by using Smart-PLS version 3.0. Brand awareness, brand image and brand association had a significant and positive influence on the satisfaction of foreign tourists and their revisit intention. The results also showed that the constraints faced by Agrotourism Rice Field Terrace in building a destination brand area, the name of Agrotourism Ceking Rice Field Terrace has not been known as a name of attractive tourist destination and the lack of handicrafts that have the characteristics of the Agrotourism.
\end{abstract}

Keywords: agrotourism, brand destination, and revisit intention

\section{INTRODUCTION}

\section{Background}

The role of agriculture as the leading sector in boosting food security is a benchmark for a country, especially a developing country like Indonesia, which is highly dependent on several sectors, one of which is the agricultural sector, apart from supporting food security; the agricultural sector can also be used as a tourist attraction. The tourism industry also has an important role in the growth and development of an area, even in some tourism areas, for example Bali. Bali tourism is one of the leading sectors besides e-ISSN: 2407-392X. p-ISSN: 2541-0857 
the agricultural sector. The natural beauty, culture, hospitality of the Balinese people, and their customs make Bali a world favorite destination.

The tourism trend with the back to nature concept encourages the development of alternative tourism models or special interest tourism that prioritizes natural conservation values and interacts with local communities that are beneficial to tourists and provide opportunities for local communities and farmers to enjoy the benefits of developing agriculture-based tourism. The trend back to nature can provide benefit for local communities from nature-based tourism activities known as nature-based tourism.

The alternative forms of tourism developed in Bali include agro-tourism activities, spiritual tourism, village tours, and ecotourism. Agro-tourism is a tourism activity that pays great attention to the agricultural and plantation sectors, such as in Ceking Village. One of the attractions of Agro tourism in Ceking Village Rice Field Terrace is the natural panorama of terraced rice fields, which are more commonly known as rice terraces which are included as a heritage that needs to be preserved.

The number of tourist arrivals to Ceking Rice Field Terrace Agrotourism after the eruption of Mount Agung decreased drastically so it is necessary to create a destination image (brand http://ojs.unud.ac.id/index.php/eot destination). This is the background of the research entitled "The Influence of Destination Brands on the Satisfaction and Revisit Intention of Foreign Tourists at the Agro-tourism of Ceking Rice Field Terrace in Bali ".

\section{Research Questions}

The research questions are structured as follows:

1. How does the destination brand influence the satisfaction of foreign tourists at Ceking Rice Field Terrace Agro Tourism?

2. How does the influence of foreign tourists' satisfaction on the revisit intention to the Ceking Rice Field Terrace Agro-tourism?

3. What are the obstacles faced in building a destination brand at Ceking Rice Field Terrace Agro tourism?

\section{Research objectives}

The objectives of this study are as follows.

1. The influence of destination brands on the satisfaction of foreign tourists at Ceking Rice Field Terrace Agro TourismPengaruh kepuasan wisatawan mancanegara terhadap niat berkunjung kembali pada Agrowisata Ceking Rice Field Terrace.

e-ISSN: 2407-392X. p-ISSN: 2541-0857 
2. Constraints faced in building destination brands at Ceking Rice Field Terrace Agro Tourism.

\section{METHODOLOGY}

\section{Research Site and Time}

This research was conducted in Ceking Village, Tegalalang Sub-District, Gianyar Regency, which was determined purposively for 3 months from April to June 2018 with the following considerations:

1. Ceking Village, Tegalalang SubDistrict, Gianyar Regency is a village that has the potential in developing agro-tourism where its strategic position is close to the tourist area of Ubud.

2. There is no similar research on the influence of destination brands on the revisit intention to Ceking Rice Field Terrace Agro Tourism.

\section{Types and Sources of Data}

The type of research data is qualitative and quantitative data. Qualitative data is used because the results of this study are descriptive by emphasizing brand of destination, satisfaction and revisit intention decisions by distributing questionnaires to respondents in the field directly. Quantitative data is used as complement and as material to support the http://ojs.unud.ac.id/index.php/eot explanations related to the substance of the research, such as data on tourist visits to Bali from books, literature, the Bali Provincial Statistics Agency, documents from related agencies or institutions, online articles and books that are able to support during the research process and the writing of the undergraduate thesis.

\section{Method of collecting data}

Data collection in this study was carried out in several ways, including reading and collecting data from existing literature and references from various books and used as a theoretical basis which supported the writing of this study and field studies aimed to cover many people so that the survey results could be seen as representative of the population or is a generalization. The form of the survey carried out is an individual survey, where the researcher carried out the survey by meeting respondents face to face. The questionnaire was designed with the aim of asking respondents to indicate their level of agreement or disagreement with a series of statements about an object.

\section{Data Analysis}

The analysis used in this research is quantitative analysis. Quantitative analysis using the SEM method with the help of Smart-PLS 3.0 software and Microsoft Excel 2016 for data tabulation. 


\section{RESULTS AND DISCUSSION}

\section{Respondent Characteristics}

The majority of respondents who visited Ceking Rice Field Terrace Agrotourism were male. Most respondents came from the UK and the least came from Italy. The highest age range of respondents was 21-30 years and the lowest was less than 20 years. The occupations of visitor respondents were varied, from entrepreneur to police / army officer. The majority of respondents knew information about Ceking Rice Field Terrace from the internet and rarely received information from radio or television advertisements. Respondents visited more with friends than with groups. On average, respondents have visited the Ceking Rice Field Terrace Agro tourism more than 3 times.

\section{Confirmatory Analysis}

Confirmatory analysis in this study is shown to draw inferences about the influence of brand awareness, brand image, brand association on satisfaction, and revisit intention of foreign tourists at Ceking Rice Field Terrace Agro Tourism. The influence of brand awareness, brand image and brand association on the satisfaction and revisit intention of foreign tourists at Ceking Rice Field Terrace Agrotourism is modeled through a structural equation model (SEM) by involving five http://ojs.unud.ac.id/index.php/eot latent variables as previously explained. The SEM model developed in this study is variance-based SEM with a model structure as shown in Figure 1 below.

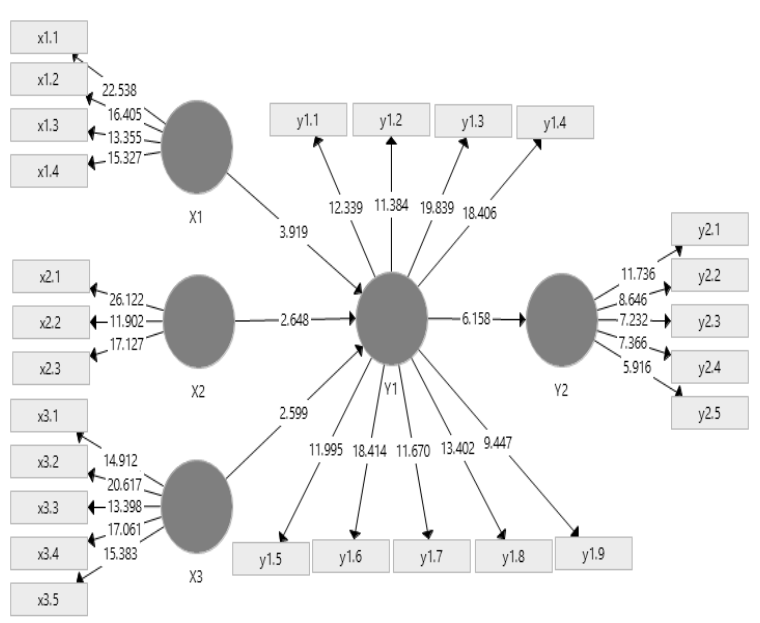

Figure 1. Structural Equation Model

\section{Outer/measurement Model}

The analysis on the outer measurement model focuses on examining the relationship between latent variables and their indicators. The indicator can be seen from the outer-loading. Testing for discriminant validity is by looking at the Average Variance Extraxted (AVE) value in the PLS model. The model requirement has good validity if each latent variable has (AVE) above 0.5. In this study, the AVE value is presented in Table 1 below. 
Table 1. Score of Average Variance Extraxted (AVE)

\begin{tabular}{lc}
\hline \multicolumn{1}{c}{ Variable } & Average Variance Extracted (AVE) \\
\hline Brand awareness & 0,729 \\
Brand image & 0,725 \\
Brand association & 0,682 \\
Satisfaction & 0,605 \\
Revisit intention & 0,604 \\
\hline
\end{tabular}

Source: 2018 Processed Primary Data

Based on the analysis shown in Table 1, the AVE value of each latent variable has a value above 0.5 and the PLS model in this study meets the requirements for discriminant validity.
This research uses cross loading values to measure discriminant validity and each latent variable must have a value of more than 0.7 .

Table 2. Discriminant Validity

\begin{tabular}{lcclllll}
\hline \multicolumn{2}{c}{ AVE } & & \multicolumn{5}{c}{ cross loading } \\
\hline variable & AVE & $\sqrt{ } \begin{array}{l}\text { brand } \\
\text { awareness } \\
\text { (X1) }\end{array}$ & $\begin{array}{l}\text { brand } \\
\text { image } \\
(\mathrm{X} 2)\end{array}$ & $\begin{array}{l}\text { Brand } \\
\text { association } \\
(\mathrm{X} 3)\end{array}$ & $\begin{array}{l}\text { Tourist } \\
\text { satisfaction } \\
(\mathrm{Y} 1)\end{array}$ & $\begin{array}{l}\text { Revisit } \\
\text { intention } \\
(Y 2)\end{array}$ \\
\hline $\begin{array}{l}\text { brand } \\
\text { awareness } \\
(\mathrm{X} 1)\end{array}$ & 0,729 & 0,853 & 0,854 & & & & \\
$\begin{array}{l}\text { brand } \\
\text { image (X2) } \\
\text { Brand }\end{array}$ & 0,725 & 0,851 & 0,167 & 0,852 & & & \\
$\begin{array}{l}\text { association } \\
\text { (X3) }\end{array}$ & 0,682 & 0,825 & 0,400 & 0,389 & 0,826 & & \\
$\begin{array}{l}\text { Tourist } \\
\text { satisfaction } \\
(Y 1)\end{array}$ & 0,605 & 0,777 & 0,592 & 0,543 & 0,630 & 0,778 & \\
$\begin{array}{l}\text { Revisit } \\
\text { intention } \\
(Y 2)\end{array}$ & 0,604 & 0,777 & 0,184 & 0,459 & 0,304 & 0,605 & 0,777 \\
\hline
\end{tabular}

Source: 2018 Processed Primary Data

Based on table 2, the analysis results show that each indicator has a cross loading of more than 0.7 compared to other variables. Indicators on brand awareness, brand image, brand association, consumer satisfaction and revisit intention have a http://ojs.unud.ac.id/index.php/eot greater correlation on the latent itself than the correlation to other latents, so that the model meets the requirements for discriminant validity. 
Model Reliability Testing

Reliability test is measuring composite reliability and cronbach'alpha on the four latent variables and the model is said to be reliable if it has a value of more than 0.7 . The results of the analysis show that all constructs have good, accurate and consistent reliability appear to meet the requirements with the composite reliability and Cronbach's alpha values for each latent construct of more than 0.7 as can be seen in Table 3 below.

Table 3. Reliability

\begin{tabular}{lll}
\hline Latent Variable & Cronbach's Alpha & Composite Reliability \\
\hline Brand awarenss & 0,876 & 0,915 \\
Brand image & 0,811 & 0,888 \\
Brand association & 0,884 & 0,915 \\
Satisfaction & 0,918 & 0,932 \\
Revisit intention & 0,838 & 0,884 \\
\hline
\end{tabular}

Source: 2018 Processed Primary Data

\section{Structural Model Analysis (Inner Model)}

The structural model or inner model is a model that describes the significance of the relationship and influence between latent variables, namely brand awareness, brand image, brand association on the satisfaction and revisit intention of foreign tourists. This study contains 4 hypotheses, the results of testing the path coefficient between exogenous and endogenous latent variables and hypothesis testing as shown in Table 4.

Table 4. Test of Structural Models and Constructed Hypotheses

\begin{tabular}{|c|c|c|c|c|c|c|c|}
\hline Hypothesis & $\begin{array}{c}\text { Exogenous } \\
\text { Variables }\end{array}$ & & $\begin{array}{c}\text { Endogenous } \\
\text { Variables }\end{array}$ & $\begin{array}{l}\text { Original } \\
\text { sample }\end{array}$ & $\begin{array}{l}\text { Standard } \\
\text { error }\end{array}$ & $\begin{array}{c}\mathrm{T} \\
\text { statistics }\end{array}$ & $\begin{array}{c}\mathrm{P} \\
\text { values }\end{array}$ \\
\hline $\mathrm{H}_{1}$ & $\begin{array}{l}\text { Brand } \\
\text { awareness }\end{array}$ & $\Rightarrow$ & $\begin{array}{l}\text { Tourists' } \\
\text { Satisfaction }\end{array}$ & 0,400 & 0,105 & 3,816 & 0,000 \\
\hline $\mathrm{H}_{2}$ & Brand image & $\Rightarrow$ & $\begin{array}{l}\text { Tourists' } \\
\text { Satisfaction }\end{array}$ & 0,346 & 0,127 & 2,725 & 0,007 \\
\hline $\mathrm{H}_{3}$ & $\begin{array}{l}\text { Brand } \\
\text { association }\end{array}$ & $\Rightarrow$ & $\begin{array}{l}\text { Tourists' } \\
\text { Satisfaction }\end{array}$ & 0,336 & 0,133 & 2,533 & 0,012 \\
\hline $\mathrm{H}_{4}$ & $\begin{array}{l}\text { Tourists' } \\
\text { satisfaction }\end{array}$ & $\Rightarrow$ & Revisit Intention & 0,605 & 0,099 & 6,130 & 0,000 \\
\hline
\end{tabular}

Source: 2018 Processed Primary Data 
Taking into account the $\mathrm{T}$ statistical values in Table 4, it is clear that the four developed hypotheses are supported significantly by the results of the structural model analysis carried out. The satisfaction of foreign tourists is significantly influenced by brand awareness with a path coefficient of 0.400 which is significant (pvalue 0.0001), brand image with a path coefficient of 0.346 is significant ( $p$-value 0.0007), brand association with a path coefficient of 0.336 is significant ( $\mathrm{p}$-value 0.0001 ) and tourist satisfaction has the greatest influence with a path coefficient of 0.605 which is already significant ( $p$-value $0.0001)$ prior to interpretation of the results of the structural equation model analysis of this study. Table 5 shows the measures commonly used to assess the feasibility of structural equation models analyzed by the SmartPLS method.

Table 5. Test of Structural Models and Constructed Hypotheses

\begin{tabular}{lcccc}
\hline \multicolumn{1}{c}{ Latent Variables } & $\begin{array}{c}\text { Types of } \\
\text { variables }\end{array}$ & $\begin{array}{c}\text { Number of } \\
\text { indicator }\end{array}$ & $\begin{array}{c}\text { Average Variance } \\
\text { Extracted (AVE) }\end{array}$ & $\mathrm{R}^{2}$ \\
\hline Brand awareness & Exogenous & 4 & 0,729 & $\mathrm{NA}^{*}$ \\
Brand image & Exogenous & 3 & 0,725 & $\mathrm{NA}^{*}$ \\
Brand association & Exogenous & 5 & 0,682 & $\mathrm{NA}^{*}$ \\
Satisfaction & Exogenous & 9 & 0,605 & 0,636 \\
Revisit intention & Exogenous & 5 & 0,604 & 0,366 \\
\hline Average & & & $0,907^{* *}$ & \\
\hline
\end{tabular}

Notes:

*: Value not available because latent is exogenous

**: The weighted average by weight is the number of indicators

Source: 2018 Processed Primary Data

Based on Table 5, it can be seen that the coefficient of determination $\left(\mathrm{R}^{2}\right)$ for endogenous latent. According to Chin et al. (1998) in Ghozali 2014, endogenous latent variables with $R^{2}$ value in the value range 0.19 to 0.33 are categorized as latent which is weakly explained; is in the range 0.33 to 0.67 categorized as latent which is moderately explained and above the value http://ojs.unud.ac.id/index.php/eot of 0.67 is categorized as substantially explained. In this study, the variable of satisfaction of foreign tourists is endogenous latent which is explained moderately, which is 0.636 by the corresponding exogenous latent, meaning that the ability of the exogenous variables of brand awareness, brand image and brand association in explaining the diversity of e-ISSN: 2407-392X. p-ISSN: 2541-0857 
foreign tourist satisfaction is $63.6 \%$, then Revisit intention, which is endogenous latent, is weakly explained, which is 0.366 , which means that the ability of the endogenous variable of foreign tourist satisfaction in explaining the level of revisit intention of foreign tourists is $36.6 \%$.

Assessing the feasibility of the structural equation model as a whole, then the Goodness of Fit (GoF) value of the above equation of $\overline{\mathrm{AVE}}$ is a weighted average value with the weight obtained from the number of indicators for each latent variable. For this formula, the GoF of the model is calculated as 0.5858 , a measure that exceeds the threshold value of 0.50 to indicate the model can be accepted and interpreted.

Table 6. Fit Model Table

\begin{tabular}{lll}
\hline & $\begin{array}{l}\text { Saturated } \\
\text { Model }\end{array}$ & $\begin{array}{l}\text { Estimated } \\
\text { Model }\end{array}$ \\
\hline SRMR & 0,089 & 0,097 \\
NFI & 0,575 & 0,570 \\
\hline
\end{tabular}

Source: 2018 Processed Primary Data

Based on table 6, the SRMR (Standardized Root Mean Residual) value of 0.089 indicates that the model is said to be feasible. The NFI (Normal Fit Index) value of 0.575 indicates a good model, because the NFI value has a range of more than 0.5 which is said to be feasible. From the results of the SRMR and NFI values, it http://ojs.unud.ac.id/index.php/eot can be said that the model in this study is feasible and fit for making predictions.

Based on the results of research on brand awareness, brand image and brand association have a positive influence on the satisfaction of foreign tourists and revisit intention at Ceking Rice Field Terrace, implications can be made which hopefully can be used as input for local governments to increase destination brands on Ceking Rice Field Terrace Agro tourism as the main choice when visiting Bali. The discussion is as follows:

a. Brand association variable

Brand awareness has a significant positive effect on the satisfaction of foreign tourists, this is based on the parameter coefficient value of 0.400 which means that it reflects a latent variable on foreign tourist satisfaction by $40 \%$, meaning that the increasing brand awareness in Ceking Rice Field Terrace will be followed by more increasing satisfaction of tourists visiting Ceking Rice Field Terrace. Ceking Rice Field Terrace's brand awareness is already good so that it affects the satisfaction of foreign tourists.

b. Brand image variable

Brand image has a significant positive effect on the satisfaction of foreign tourists. This is based on the value of the parameter coefficient of 0.346, which means that it reflects a latent variable on the satisfaction of foreign consumers of $34.6 \%$, which 
means that the increasing brand image of Ceking Rice Field Terrace will be followed by an increase in the satisfaction of foreign tourists. This proves that the brand image, especially the beauty of the rice fields, is already good so that it affects the satisfaction of foreign tourists and their future revisit intention.

c. Brand association variable

Brand association has a significant positive effect on the satisfaction of foreign tourists. This is based on the value of the parameter coefficient of 0.336 which means that it reflects a latent variable on the satisfaction of foreign tourists by $33.6 \%$, which means that the increasing of the Ceking Rice Field Terrace brand association will be followed by an increase in the satisfaction of foreign tourists. This proves that the brand association is good so that it affects the satisfaction of foreign tourists.

d. Variable of satisfaction of foreign tourists

The satisfaction of foreign tourists has a positive influence on revisit intention. This is based on the parameter coefficient value of 0.605 which means that it reflects a latent variable on revisit intention of $60.5 \%$, which means that the more satisfied tourists are with Ceking Rice Field Terrace Agrotourism, the higher the revisit intention rate will be. The satisfaction of foreign tourists has proven that it has an influence on revisit intention.

The obstacles faced in building a destination brand on Ceking Rice Field Terrace Agro-tourism are the fact that the Ceking area has not been widely known as a tourist destination. Foreign tourists are more familiar with Ceking by the name Tegalalang, so a more intense promotion is needed in introducing the name Ceking as a tourist destination in Gianyar. In other words, it is lack of promotion of the name Ceking Rice Field Terrace by the local community to visiting foreign tourists. Another obstacle is the unavailability of handicrafts that have the characteristics of Ceking Rice Field Terrace Agro-tourism.

\section{CONCLUSIONS}

\section{Conclusions}

1. Destination brands consisting of brand awareness, brand image and brand association have a significant effect on the satisfaction of foreign tourists in visiting Ceking Rice Field Terrace Agro Tourism.

2. The satisfaction of foreign tourists has a significant effect on revisit intention to visit Ceking Rice Field Terrace Agrotourism. Overall, it can be said that the destination brand significantly affects satisfaction and revisit intention.

\footnotetext{
e-ISSN: 2407-392X. p-ISSN: 2541-0857
} 
3. The obstacles faced in building a destination brand on Ceking Rice Field Terrace Agro-tourism are the fact that the Ceking area has not been widely known as a tourist destination. Foreign tourists are more familiar with Ceking by the name Tegalalang, so a more intense promotion is needed in introducing the name Ceking as a tourist destination in Gianyar. In other words, it is lack of promotion of the name Ceking Rice Field Terrace by the local community to visiting foreign tourists. Another obstacle is the unavailability of handicrafts that have the characteristics of Ceking Rice Field Terrace Agro-tourism.

\section{Suggestions}

Based on the research results, the following suggestions can be proposed.

1. To increase the number of tourist visits, it is necessary to promote through information on social media regarding knowledge and history about Ceking Rice Field Terrace Agro-tourism, so that in the future visiting tourists will know more about Ceking Rice Field Terrace Agro-tourism to be visited.

2. This study is only limited to measuring the effect of brand awareness, brand image and brand association on the revisit intention of foreign tourists. It is hoped that in future studies it can add http://ojs.unud.ac.id/index.php/eot several variables and use the latest analysis methods and tools, so as to provide more perfect research results.

\section{ACKNOWLEDGEMENTS}

The author's gratitude goes to the supervisors and all parties who have helped carry out research so that this scientific work can be published in e-journals.

\section{REFERENCES}

Diarta, S. 2017. Between Cultural Preservation and Tourism Industry: Dialectic Relations in Cultural Heritage Tourism Management in Tanah Lot and Borobudur Indonesia vol 4 no.2. Denpasar: Universitas Udayana

Ghozali, I. 2014. Structural Equation Modeling Metode Alternatif dengan Partial Least Square Aplikasi. Cetakan keempat. Semarang: Universitas Diponogoro

Hair, Charles W. Lamb, Joseph F, Carl Mcdaniel. 2001. Pemasaran. Edisi Pertama, Salemba Empat, Jakarta.

Kotler dan Gary Amstrong. 2012. PrinsipPrinsip Pemasaran Edisi 13, Jilid 1. Jakarta. Erlangga

Suryawardani, I G.A.O. 2018. Evaluation of Marketing Strategy of Sanur Village Festival Baesd on Visitors' Behaviour. International Journal of Applied Business and Economic Research, Vol. 16 Number 2, 2018, page 216-276. ISSN 0972-7302.

e-ISSN: 2407-392X. p-ISSN: 2541-0857 
Suryawardani, I G.A.O., A.S. Wiranatha, 1

K.G. Bendesa, M. Antara and Maria Gravari-Barbass. 2017. A Structural Model of Foreign Tourists' Loyalty in Nature-based Tourism in Bali. International Journal of Applied Business and Economic Research, Vol. 15, Number 9. 2018, page 195215 (2017). ISSN 0972-7302.

Suryawardani, I G.A.O., and A.S. Wiranatha. 2015. Destination Marketing Strategy in Bali through Optimizing the Potential of Local Products. E-Journal of Tourism. Vol.1. No.1. (2014). Page: 35-49. ISSN: 2407-392X

Suryawardani, I G.A.O., and A.S. Wiranatha. 2016. Assessment of Guests' Perception in Implementation of Green Hotel in Supporting Sustainable Tourism. EJournal of Tourism Vol.3. No.1. (2016). Page: 21-32. ISSN: 2407-392

Wiranatha, A.S. 2015. Sustainable Development Strategy for Ecotourism at Tangkahan, North Sumatera. EJournal of Tourism Vol.2. No.1. (2015). Page:1-8. ISSN: 2407-392X.

Wiranatha, A.S., and I G.A.O. Suryawardani. 2018. A Structural Model of Community Based Agrotourism Development at The World Heritage Site of Jatiluwih Rice Field Terrace in Tabanan, Bali. Journal of Global Stochastics Analysis, Vol. 5 Number 7 (2018), page; 65-81. ISSN: 2248-94444.

Wiranatha, A.S., I G.A.O. Suryawardani, and 1 K.G. Bendesa. 2018. Model of Foreign Tourist' Loyalty in Cultural and Heritage Tourism. Journal of Global Stochastics Analysis.
Wiranatha, A.S., I G.A.O., Suryawardani, 1 K.G. Bendesa and M. Antara. 2016. Model of Foreign Tourist's Loyalty on Marine Tourism to Visit Bali. Internasional Journal of Multidisciplinary Educational Research, Volume 5, Issue 3 (2), 2016. 